\title{
Study on the Treatment of Postoperative Pain in Patients Operated for Incisional Hernia by Open or Laparoscopic Approach
}

\author{
BOGDAN ANDREI SUCIU ${ }^{1,2}$, CRISTIAN TRAMBITAS ${ }^{1 *}$, VLAD VUNVULEA ${ }^{1}$, DUMITRU GODJ A ${ }^{2}$, REKA KALLER $^{3}$, DECEBAL FODOR $^{1}$, \\ KLARA BRINZANIUC ${ }^{1}$, CALIN MOLNAR ${ }^{2}$, IOANA HALMACIU ${ }^{1}$ \\ ${ }^{1}$ University of Medicine and Pharmacy Tirgu Mures,Anatomy Discipline,39 Gheorghe Marinescu Str., 540142, Targu Mures, \\ Romania \\ ${ }^{2}$ Surgery Clinic no.1, Mures County Clinical Emergency Hospital, 50 Gheorghe Merinescu Str., 540136, Tirgu Mures, Romania \\ ${ }^{3}$ Vascular Surgery Department, Mures County Clinical Emergency Hospital,50 Gheorghe Merinescu Str., 540136, Tirgu Mures, \\ Romania
}

\begin{abstract}
Postoperative pain is a common symptom in the postoperative period in patients treated for incisional hernia, often refractory to treatment. The purpose of the this paper was to conduct a comparative study on the need for analgesic medication in patients operated for incisional hernia through a classical open approach and a laparoscopic approach. In this respect, we performed a retrospective observational study over a period of 4 years in which we introduced 92 patients operated for incisional hernia in the Surgery Clinic No. 1 of the Emergency County Hospital Tirgu Mures. For the reconstruction of the abdominal wall we used prosthetic materials (surgical meshes). All patients included in the study received only metamizole sodium as analgesic medication. The patients studied were divided into two groups: group A (consisting of 57 patients where open, classic surgical approach was used) and group B (consisting of 35 patients treated using a minimally invasive laparoscopic approach). It was observed that on the day of surgery and during the first two postoperative days there are no statistically significant differences in the need for analgesic medication between the studied groups. Instead, starting with the third postoperative day, the need for analgesic medication is much lower in patients where laparoscopic surgical procedure was used than in those where open, classic surgical approach was used.
\end{abstract}

Key words : analgesia, incisional hernia, classic approach, laparoscopic approach

Incisional hernias are quite common conditions that occur in patients with a history of abdominal surgery, affecting about $20 \%$ of patients with a history of abdominal surgery. In patients with a history of abdominal wall infections, the prevalence of incisional hernias may reach $50 \%$. [1-3]. In the last decade, the incidence of incisional hernias has increased quite a bit, mainly due to the increase in abdominal surgeries, due to increased life expectancy as well as the increase in the rate of obesity [4].

Surgical treatment of incisional hernias can be performed with or without prosthetic material. If prosthetic materials are not used in abdominal wall reconstruction techniques in incisional hernias, it has been proven that the rate of recurrence of the incisional hernias may reach $30 \%$. Despite this fact, there are authors who still recommend to practice simple sutures in case of incisional hernias with a diameter of less than $3 \mathrm{~cm}$ [5-7]. With this in mind, the vast majority of authors recommend the use of prosthetic materials in the surgical treatment of incisional hernias and abdominal wall hernias [8] .

Currently, the surgical treatment of incisional hernias benefits of either open, classic or laparoscopic approach, depending on experience of the surgical team. The advantage of the laparoscopic approach is mainly the fact that it is a minimally invasive approach with lower morbidity and postoperative mortality compared to the classic open approach, also favoring a faster social reintegration of these patients. The major disadvantage of the laparoscopic approach is mainly the much higher cost of surgery, thus this surgical approach is not widely used [9].

The purpose of this paper was to conduct a comparative study on the need for analgesic medication in patients operated for incisional hernias, both through open, classic and laparoscopic approaches.

\section{Experimental part}

We have carried out a retrospective observational study over a period of 4 years, in which we included 92 patients operated for incisional hernias in the Surgery Clinic no. 1 of the County Emergency Hospital Tirgu Mures. The patients studied were divided into two groups: group A consisting of 57 patients (where the surgical treatment of the postoperative hernia was conducted using a open, classic approach with polypropylene mesh positioned over the aponeurosis) and B group of 35 patients (who underwent surgical treatment of the incisional hernia through a laparoscopic approach with Parietex ${ }^{\mathrm{TM}}$ mesh positioned pro-peritoneal) (fig. 1, 2)

The surgical mesh used in laparoscopic patients is characterized by the fact that it is a polyester mesh that is

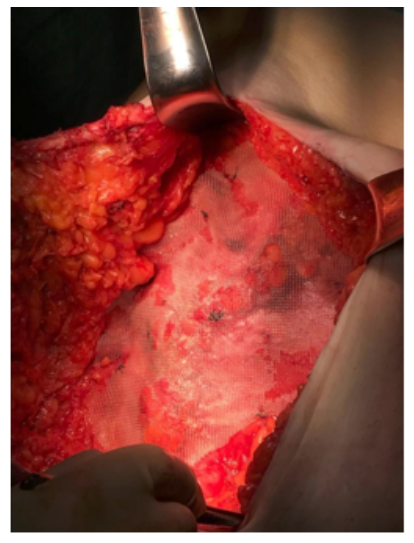

Fig. 1. Polypropylene mesh positioned over the aponeurosis (surgical open, classic approach)

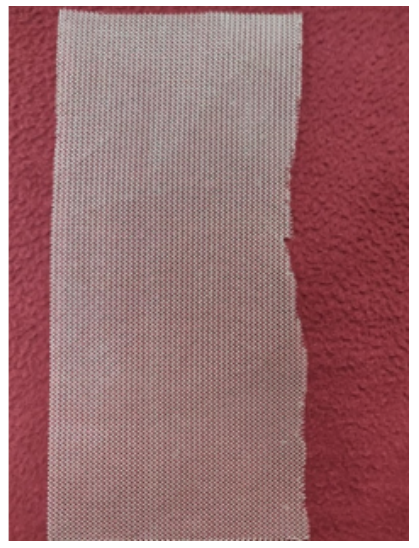

Fig. 2. Polypropylene mesh

*email: c trambitasu@yahoo.com, Phone: (+40)745615113 
covered by a collagen film and has polylactic acid micro hooks (bioresorbable). The advantage of these micro hooks is that they provide better tissue integration and shorten the time of surgery, and it is not necessary to fasten the mesh to the abdominal wall using sutures (fig. .3).

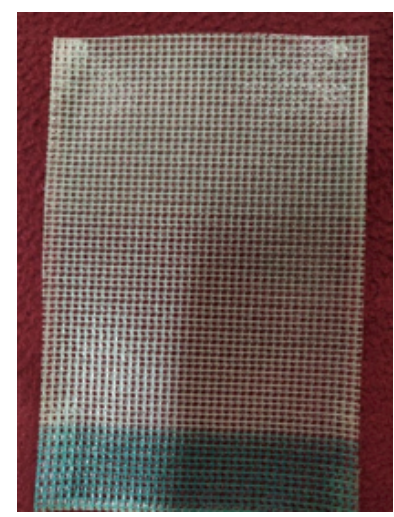

Fig. 3. Surgical mesh used in laparoscopic approach

The data required for the study was obtained from the hospital's integrated computer system. For all patients included in the study we recorded the following parameters: age, sex, type of surgery, need for analgesic medication on the day of surgery and during the first 4 days after the procedure. In order to improve the quality of the statistical analysis, we only included patients who used as analgesic medication metamizole sodium $1 \mathrm{~g} / 2 \mathrm{~mL}$ (Algocalmin ${ }^{\mathrm{TM}}$ ), excluding patients who received other types of analgesic medication. Also, to improve the accuracy of the statistical data, we excluded patients who experienced local postoperative complications (hematomas, seromas or abdominal wall infections) because these conditions can exponentially increase the need for analgesic medication in such patients.

The statistical analysis of the data was done using the Microsoft Excel and GraphPad software. When performing the statistical analysis, we considered that there is a
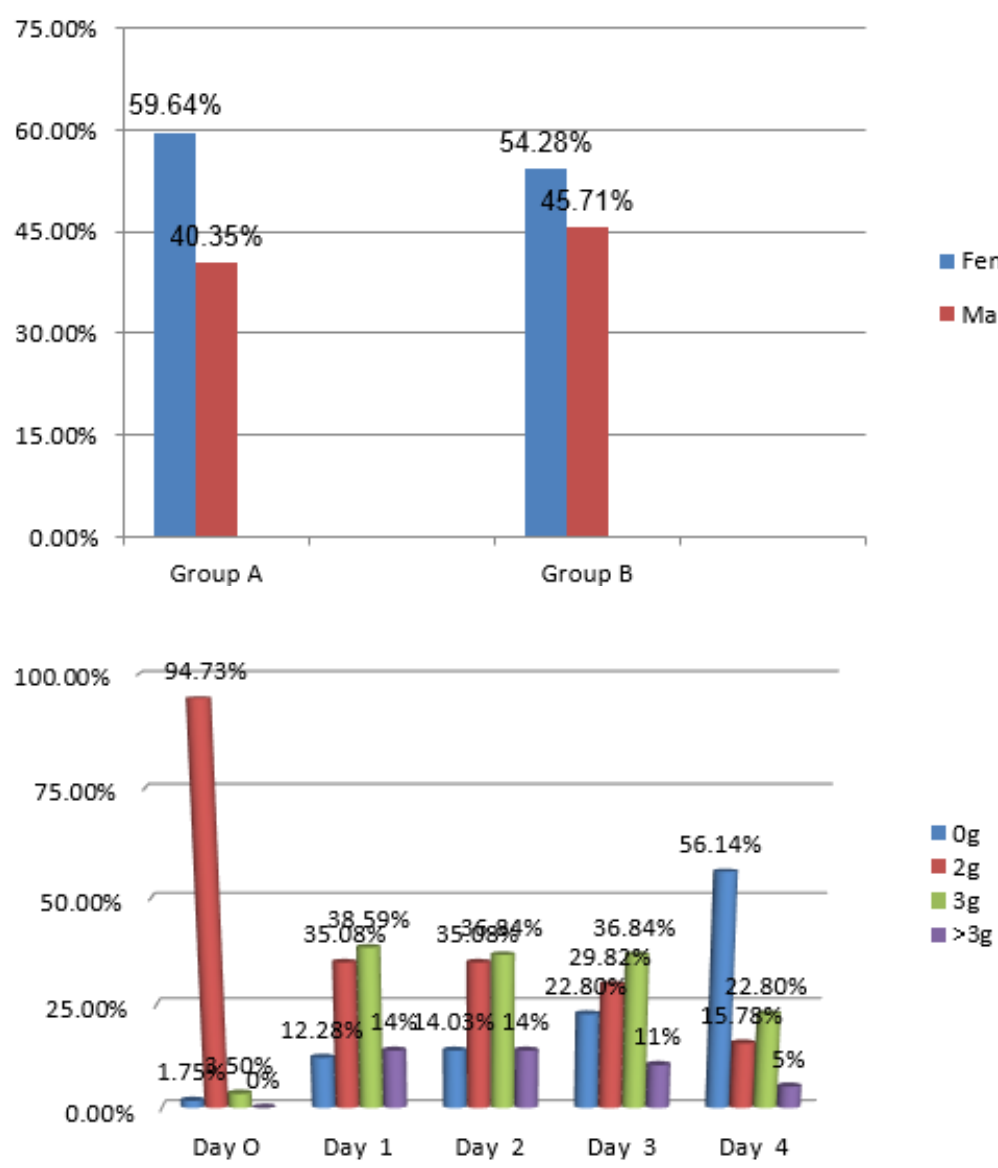

- Female

- Male

$-2 \mathrm{~g}$

3g

$>3 \mathrm{~g}$

Fig. 4. Distribution by gender of the patients

Fig. 5. The amount of analgesic medication administered to patients in group $\mathrm{A}$ 


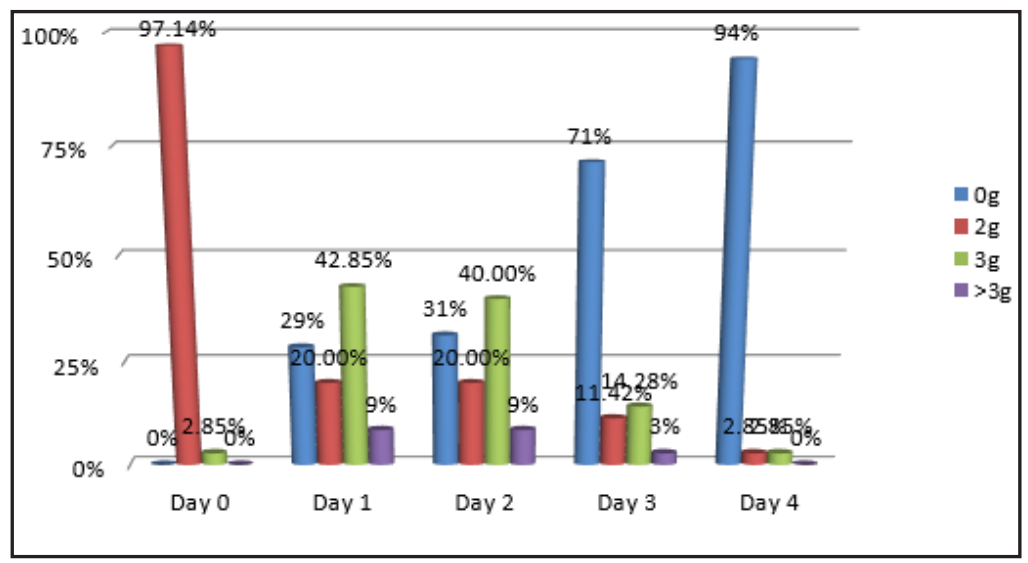

Fig. 6. The amount of analgesic medication administered to patients in group $B$

a little lower in the case of laparoscopic surgical cure of the incisional hernia, after statistic analysis we did not obtain any statistically significant differences between the two studied groups $(p=0,226)$. The data is presented in table 2.

Table 1

STATISTICAL ANALYSIS ON THE ANALGESIC MEDICATION REQUIREMENT BETWEEN THE TWO GROUPS, THE DAY OF SURGERY

\begin{tabular}{|l|l|}
\hline Table Analyzed & Column: Entering replicate data \\
\hline Column B & laparoscopic z0 \\
vs. & vs. \\
Column A & clasic z0 \\
\hline Unpaired t test & \\
P value & 0.5578 \\
P value summary & ns \\
Significantly different (P < 0.05$) ?$ & No \\
One- or two-tailed P value? & Two-tailed \\
t, df & $t=0.5884$, df $=90$ \\
\hline How big is the difference? & \\
\hline Mean of column A & 1.526 \\
\hline Mean of column B & 1.600 \\
\hline Difference between means (B - A) & $0.07368 \pm 0.1252$ \\
\hline $95 \%$ confidence interval & -0.1751 to 0.3225 \\
R squared (eta squared) & 0.003831 \\
\hline
\end{tabular}

On the 2nd postoperative day we found out that for lot A the mean analgesic medication needed was $2.421 \mathrm{~g}$ of metamizole sodium whereas for lot B it was $2.029 \mathrm{~g}$ of metamizole sodium. Even in this case we did not obtain any statistically significant differences between the two studied lots, the value $p$ being of 0.198 (table 3 ).

From the statistical analysis of demand of analgesic medication on the 3rd postoperative day we noticed that there are statistically significant differences between the two studied groups $(p<0.001)$. We also noticed that, for lot $A$, the average analgesic medication requirement was $2.175 \mathrm{~g}$ of metamizole sodium and, in the case of $\mathrm{B}$, the average analgesic requirement was $0.771 \mathrm{~g}$ metamizole sodium (table 4).

Regarding the analysis of data obtained on the 4th postoperative day, we noticed that there is a statistically significant difference between the two lots studied regarding the analgesic medication requirement, the need for analgesic medication was much higher in case of group $A(p<0.001)$ as highlighted in table 5 . It should be noted
Table 2

STATISTICAL ANALYSIS ON THE ANALGESIC MEDICATION REQUIREMENT BETWEEN THE TWO GROUPS, THE FIRST POSTOPERATIVE DAY

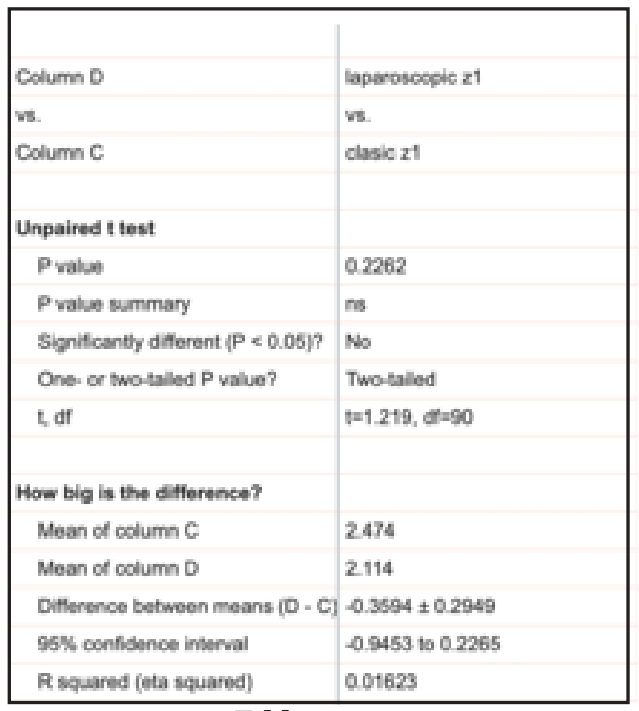

Table 3

STATISTICAL ANALYSIS ON THE ANALGESIC MEDICATION REQUIREMENT BETWEEN THE TWO GROUPS, THE SECOND POSTOPERATIVE DAY

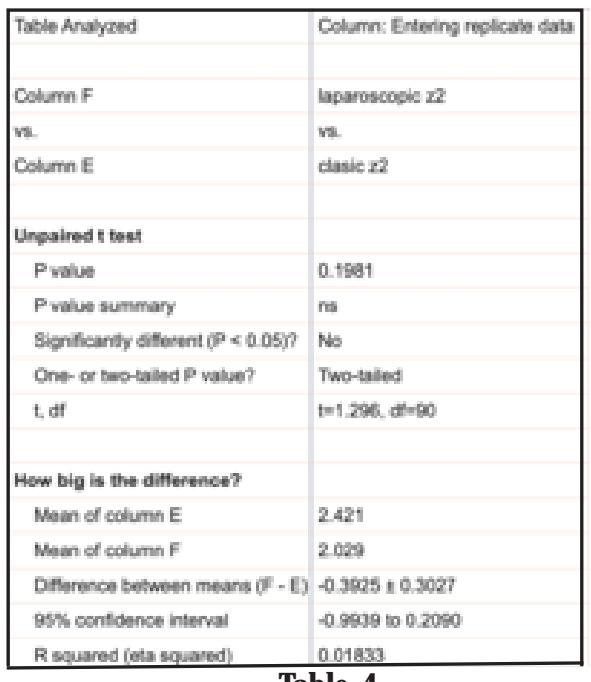

STATISTICAL ANALYSIS ON THE ANALGESIC MEDICATION REQUIREMENT BETWEEN THE TWO GROUPS, THE THIRD POSTOPERATIVE DAY

\begin{tabular}{|c|c|}
\hline Table Analyzed & Column: Entering replicate data \\
\hline Column H & laparoscopic z3 \\
\hline vis. & vs. \\
\hline Column G & clasic Z3 \\
\hline \multicolumn{2}{|l|}{ Unpaired $\mathrm{t}$ test } \\
\hline P value & $<0.0001$ \\
\hline$P$ value summary & $\cdots$ \\
\hline Significantly diflerent $(P<0.05)$ ? & Yes \\
\hline One- or two-tailed $P$ value? & Two-tailed \\
\hline $\mathrm{t}, \mathrm{df}$ & $\mathrm{t}=4.779, \mathrm{df}=90$ \\
\hline \multicolumn{2}{|l|}{ How big is the difference? } \\
\hline Mean of column $G$ & 2.175 \\
\hline Mean of column $\mathrm{H}$ & 0.7714 \\
\hline Difference between means $(\mathrm{H}=\mathrm{G}$ ) & $-1.404 \pm 0.2938$ \\
\hline $95 \%$ confidence interval & -1.988 to -0.8204 \\
\hline R squared (eta squared) & 0.2024 \\
\hline
\end{tabular}


Table 5

STATISTICAL ANALYSIS ON THE ANALGESIC MEDICATION REQUIREMENT BETWEEN THE TWO GROUPS, THE FOURTH POSTOPERATIVE DAY

\begin{tabular}{|c|c|}
\hline Table Analyzed & Column: Entering replicate data \\
\hline Column J & laparoscopic z4 \\
\hline vs. & vo. \\
\hline Column I & clasic z4 \\
\hline \multicolumn{2}{|l|}{ Unpaired $\mathrm{t}$ test } \\
\hline P value & $<0.0001$ \\
\hline P value summary & ... \\
\hline Significantly difterent $(P<0.05)$ ? & Yes \\
\hline One- or two-tailed $P$ value? & Two-tailed \\
\hline$t$, af & $t=4.745, d f=90$ \\
\hline \multicolumn{2}{|l|}{ How big is the difference? } \\
\hline Mean of column I & 1.088 \\
\hline Mean of column J & 0.000 \\
\hline \multicolumn{2}{|c|}{ Difference between means $(J-1) \leq-1.088 \pm 0.2292$} \\
\hline $95 \%$ confidence interval & -1.543 to -0.6323 \\
\hline R squared (eta squared) & 0.2001 \\
\hline
\end{tabular}

that since we only entered patients without postoperative complications, all patients who were operated laparoscopically were discharged on the 4th postoperative day.

In our study, we noticed that there is no significant difference in the first 2 days after the operation in terms of the need for analgesic medication in patients undergoing surgery for incisional hernia. Instead on the 3rd and 4th postoperative day the need for analgesic medication is lower in laparoscopic treated patients. This is probably due to the fact that the laparoscopic approach is minimally invasive while also determining a faster recovery of bowel motility.

In the past decades, more and more types of heterologous materials are used in medicine, both in tissue repair techniques and in various simulation or learning techniques. Such an example is given by the use of surgical meshes made out of plastic materials [10-12].

All patients with incisional hernia at the time of diagnosis had the indication of surgical treatment on the one hand due to complications that may occur (strangulated incisional hernia, necrosis of a segment of the intestine) as well as the fact that the volume increase of the incisional hernia may affect the quality of life of these patients [13,14].

The main factors that the success of surgery in incisional hernias depends on are : the surgical technique used and the existence of certain conditions that may adversely influence the postoperative progression of these patients, such as: anemia, renal failure, diabetes mellitus, vitamin deficiency, the presence of jaundice or abdominal wall infection $[15,16]$.

There is controversy in the literature regarding the best surgical technique used in the surgical treatment of patients with incisional hernias. Nowadays there are two surgical approaches: open, classic approach and laparoscopic approach. The vast majority of published studies have shown that there is no difference in the longterm rate of recurrence of incisional hernias, regardless of whether open, classic or laparoscopic surgical approach is practiced $[17,18]$. On the other hand, some studies have shown that the incidence of immediate local postoperative complications (hematomas, seromas, abdominal wall infections) is lower when using the laparoscopic approach in patients with incisional hernias $[19,20]$.
The vast majority of studies published in the literature recommend surgical techniques for reconstruction of the abdominal wall in patients with incisional hernias with prosthetic materials (surgical meshes). One of the main advantages of their use is the fact that after the tissue integration of the surgical mesh there is an increase of the resistance of the abdominal wall [21,22].

In the open surgical approach, the most common type of surgical mesh used in such patients is polypropylene mesh. The advantage of the polypropylene mesh is that it exhibits very good tissue integration, with graft rejection being lower compared to other types of surgical meshes [23]. In addition to abdominal wall reconstructions in patients with incisional hernias, the polypropylene mesh is also used in thoracic surgery, in thoracic surgical techniques after extensive thoracic wall resections or in bronchial stump closure techniques after lung resections [24,25].

In the case of laparoscopic surgery, the surgical mesh is inserted properitoneally between the plane of the abdominal rectus muscles and the anterior parietal peritoneum (Rives-Stoppa technique). Compared to other surgical techniques (placement of the mesh over the aponeurosis) some authors consider that the relapse rate of the incisional hernia is lower in such cases. [26,27]. Even if this surgical technique predisposes to a lower relapse rate, the existence of complications related to the presence of the mesh in the abdominal wall is possible. The main such postoperative complications that may occur are: hematomas, seromas, abdominal wall infections or chronic pain. Chronic pain most commonly occurs due to suturing of a nerve inside the suture line that fixes the mesh to the abdominal wall or by the irritation of a nerve in the abdominal wall by the suture material [28-30] .

Instead, the laparoscopic approach has the disadvantage that for technical reasons it can not be used in all patients with incisional hernias. Thus it is considered that in cases of incisional hernias with abdominal parietal defect located near the rib cage or pelvis, trough laparoscopic approach it is not possible to treat these incisional hernias correctly due to the impossibility of placing and fixing the mesh at the level of the defect in a correct position [31-33].

In our study, in patients where laparoscopic surgical approach was used, the surgical mesh we chose was polyester mesh. The major advantage of this type of mesh is that the surface of the mesh is covered with micro-hooks of polylactic acid that secures the mesh to the tissues. The existence of these hooks fastens the mesh at the tissue level much better, with a lower need for sutures in these cases. Another advantage is given by the fact that polylactic acid is a bioresorbable substance $[34,35]$. These types of meshes are also covered by a collagen film. The existence of collagen in these cases has the role to prevent the formation of adhesions between the intestines and the abdominal wall, as well as to prevent the occurrence of possible enterocutaneous fistulas [36].

One of the main factors influencing the occurrence of postoperative pain in patients with incisional hernias is the method of fixation of the surgical mesh. In the case of open surgical approach, the mesh is fixed to the abdominal wall using sutures, whilst in the case of laparoscopic approach, the mesh is fixed to the abdominal wall using either tacks or sutures. Certain studies in laparoscopic surgical patients with incisional hernias have shown that there are no statistically significant differences in the incidence of postoperative pain between the two techniques of mesh fixation [37].

There are also studies published in the literature that analyze the incidence of postoperative pain, depending on 
the type of suture or staples used (resorbable or nonresorbable). In this respect, it has been shown that the type of abdominal wall fixation technique does not influence the incidence of postoperative pain [38,39].

\section{Conclusions}

Although in the immediate postoperative period the need for analgesic medication is not different in patients where the surgical cure of the incisional hernia is practiced by laparoscopic or classic approach, starting with the third postoperative day, the patients where laparoscopic approach is practiced, require less analgesic medication than in patients where open, classic surgery is practiced.

\section{References}

1.BIKHCHANDANI J., FITZGIBBONS RJ jr., Adv. Surg., 47,2013,p.1-27 2.HALMACIU, I., SUCIU, BA., FODOR, D., GODJA, D., TRAMBITAS, C., VUNVULEA, V., BRINZANIUC, K., MOLNAR, C., Mat. Plast., 55, no. 2, 2018,p.207-210

3.MULLASSERY D., PEDERSEN A., ROBB A., SMITH N., J. Pediatr. Surg., 51, 2016,nr.11,p.1791-1794

4.HALLIGAN S., PARKER SG., PLUMB AA., WINDSOR AC] ., Eur. Radiol., 28,2018,nr.8,p.3560-3569

5.AKCAKAYA A., AYDOGDU I., CITGEZ B., Exp. Ther. Med., 15,2018,nr.2,p.1622-1625

6.ANDERSEN LP., KLEIN M., GOGENUR I., ROSENBERG J ., BMC. Surg., $\mathbf{2 8 , 2 0 0 9 , n r . 9 , p . 6}$

7.KINGSNORTH A., Ann. R. Coll. Surg. Engl., 88,2006,nr.3,p.252-260 8.DE VRIES REILINGH TS., VAN GOOR H., CHARBON JA., ROSMAN C., HESSELINK EJ., VAN DER WILT G] ., BLEICHRODT RP., World. J. Surg., 31,2007,nr.4,p.756-763

9.TANDON A., PATHAK S., LYONS NJ ., NUNES QM., DANIELSIR., SMART NJ ., Br. J. Surg., 103,2016,nr.12,p.1598-1607

10.BADAU D., BADAU A., Int. J. Environ. Res. Public. Health., 15,2018, nr.12,p.1-20

11.POP, TS., POP, AM., TRAMBITAS MIRON, AD., BRINZANIUC, K., GURZU, S., TRAMBITAS, C., Mat. Plast., 55, no. 4, 2018, p.691-695 12. HALMACIU, I., SUCIU, BA., TRAMBITAS, C., VUNVULEA, V., IVANESCU, A., CLIPA, A., ADASCALITEI, P., BRINZANIUC, K., FODOR, D., Mat. Plast., 55, no. 3, 2018, p.414-418

13.KRPATA DM., SCHM3TZER BJ ., FLOCKE S., JIN J., BLATNIK JA., ERMLICH B., NOVITSKY YW., ROSEN MJ., J. Am. Coll. Surg., 215,2012,nr.5,p.635-642

14.SUCIU, B.A., HALMACIU, I., FODOR, D., TRAMBITAS, C., IVANESCU, A., GODJA, D., VUNVULEA ,V., MOLNAR, C., BRINZANIUC, K., Mat. Plast., 55, no. 2, 2018,p.152-155

15.WALMING S., ANGENETE E., BLOCK M., BOCK D., GESSLER B., HAGLIND E., BMC. Surg., 17,2017,nr.1,p.19
16.RYAN TJ ., Curr. Opin. Infect. Dis., 20,2007,nr.2,p.124-128

17.KOCKERLING F., SCHUG-PASS C., SCHEUERLEIN H., Front Surg., $13,2018, n r .5, p .47$

18.AL CHALABI H., LARKIN J., MEHIGAN B., MCCORMICK P., Int J Surg., 20,2015, p.65-74

19.AWAIZA., RAHMAN F., HOSSAIN MB., YUNUS RM., KHAN S., MEMON B., MEMON MA., Hernia., 19,2015,nr.6,p.1027-1029

20.J ENSEN KK., J ORGENSEN LN., Hernia., 19,2016,nr.6,p.1025-1026 21.MAKELA JT., KIVINIEMI H., JUVONEN T., LAITINEN S., Am. J. Surg., $170,1995, n r .4, p .387-390$

22.FRANKLIN RR., Obstet. Gynecol., 86,1995,nr.3,p.335-340

23.SUCIU, B.A., HALMACIU, I., FODOR, D., TRAMBITAS, C., GODJA, D., CLIPA, A., NICOLESCU, C., BRINZANIUC, K., VUNVULEA, V., Mat. Plast., 55, no. 3, 2018,p.380-384

24.SUCIU BA., HALMACIU I., VUNVULEA V., BRINZANIUC K., Eur. J. Cardiothorac. Surg., 53,2018,nr.4,p.895-896

25.BADAU, A., BADAU, D., CLIPA, A., Mat. Plast., 55, no. 4, 2018, p.600602

26.ERIKSSON A., ROSENBERG J., BISGAARD T., Hernia., 18,2014,nr.1,p.31-38

27.PAULI EM., ROSEN MJ ., Surg. Clin. North. Am., 93,2013,nr.5,p.11111133

28.VERHELST J ., DE GOEDE B., KLEINRENSINK G . , JEEKEL J ., LANGE JF., VAN EEGHEM KH., Int. J. Surg., 13,2015,nr.1,p.184-188

29.DE VRIES REILINGH TS., VAN GOOR H., CHARBON JA., ROSMAN C., HESSELINK EJ., VAN DER WILT GJ ., BLEICHRODT RP., World. J. Surg., 31,2007,nr.4,p.756-763

30.ROSEN MJ., Am. J. Surg., 197,2009,nr.3,p.353-359

31.KINGSNORTH A., BANERJ EA A., BHARGAVA A., Ann. R. Coll. Surg. Engl., 91,2009,nr.8,p.631-636

32. MISIAKOS EP., MACHAIRAS A., PATAPIS P., LIAKAKOS T., JSLS., $12,2008, n r .2, p .117-125$

33.SHEEN AJ., PILKINGTON J]., BALTATZIS M., TYURKILMAZ A., STATHAKIS P., JAMDAR S., SIRIWARDENA AK., BMC. Surg., $18,2018, n r .1, p .46$

34.CHASTAN P., Hernia., 13,2009,nr.2,p.137-142

35.KINGSNORTH A., GINGELL-LITTLEJ OHN M., NIENHUIJSS., SCHULE S., APPEL P., ZIPRIN P., EKLUND A., MISEREZ M., SMEDS S., Henia., $16,2012, \mathrm{nr} .3, \mathrm{p} .287-294$

36.HUTAN M., BARTKO C., MAJESKY I., PROCHOTSKY A., SEKAC J., SKULTETY J., BMC. Surg., 14,2014,nr.1,p.50

37.REYNVOET E., DESCHEPPER E., ROGIERS X., TROISI R., BERREVOET F., Langenbeck's Arch. Surg., 399,2014,nr.1,p55-63 38.WASSENAAR E., SCHOENMAECKERS E., RAYMAKERS J., VAN DER PALEN J., RAKRIC S., Surg. Endosc., 24,2010,nr.6,p. 1296-1302 39.MUYSOMS F., VANDER MIJ NSGRUGGE G., PLETINCKX P., BOLDO E., JACOBSI., MICHIELSM., CEULEMANS R., Hernia., 17,2013,nr.5,p.603612

Manuscript received: 15.12 .2018 